\title{
Multi-layered socialization processes in transgenerational family firms
}

Abstract: Building on an in-depth case study of a four-generational Scottish family firm, we generate a triple-layered model of socialization. Our findings go beyond the traditional focus on internal family socialization and value transmission, and suggest that socialization involves three concentric layers unfolding over time, each with a distinct set of dimensions, values, challenges and processes: internal (transmitting knowledge within the family), interactive (resolving competing role demands through peer interactions) and experiential (interacting with both peer groups and malleable societal/economic frames). This novel theorization provides a promising framework for future research seeking to explain the complexities of socialization processes in transgenerational family firms.

Keywords: succession; socialization; context; case study.

\section{INTRODUCTION}

Socialization is "the process by which people selectively acquire the values and attitudes, the interests and knowledge in the groups of which they are, or seek to become, a member. It refers to the learning of social roles" (Merton, 1957: 287). How family members are 'socialized' into the family business has been of fundamental concern for scholars and practitioners interested in 'continuity' and 'succession' in family businesses. Socialization models, so far, have emphasized a linear and unidirectional flow of information, values, and norms from older to younger generation family members (Foster, 1995; García-Álvarez et al., 2002; Haag, 2012) and have focused on three aspects. First, much research has explored family business socialization as an internalization process of value transmission and on-thejob training of a founder's descendants. It has focused particularly on how successors are motivated, 'groomed' and developed to gradually take over the family business and play a stable role in its management (Cabrera-Suárez et al., 2001; García-Álvarez et al., 2002; Dyck et al., 2002; Cater and Justis, 2009; Le Breton-Miller and Miller, 2015; Jaskiewicz et al., 2015). A second aspect of family business socialization research has examined the nature and impact of mutual role adjustment (or maladjustment) between incumbents and nextgeneration family members in various succession stages (Handler, 1990; 1994; Miller et al., 2003; Cater and Justis, 2009). A third aspect has been gender socialization, in which researchers have noted that women in family businesses experience a radically different form of socialization than their male counterparts, leading to few women being considered as 
potential successors (Mulholland, 1996; Hamilton, 2006). There is thus an extensive body of family business research on how family members can best transmit general business management skills to the next generation (Rosa et al., 2014).

Parallel to this family business research has been a considerable expansion in the volume and theoretical development of sociological and psychological research on socialization during the last half century. Of particular note has been theoretical shifts in the wider socialization literature from Parsonian and normative functionalist views of 'internalized' socialization to a more dynamic and interpretivist theoretical position that emphasizes the interaction of multiple external and internal factors influencing socialization (Wrong, 1961; Jones, 1983; Grbich, 1990; Abrantes, 2013a; 2013b). Family business researchers on socialization have demonstrated limited awareness of this shift, perhaps reflecting that the field in the last few decades has become "skewed" towards "the business rather than the family system" (Sharma et al., 2014: 3, James et al., 2012), with less attention paid to sociological theory than theory from business economics and strategy. This relative lack of awareness represents an opportunity to explore how these new theoretical perspectives could add value to our understanding of socialization processes in family firms. We take on this opportunity to develop a multi-layered model of how and why different forms of socialization prevail over time in transgenerational family firms. We suggest that only some family businesses benefit from traditional normative forms of socialization, but others less so. 'One size does not fit all'. The paper contributes to the literature by illustrating the advantages of broadening the agenda of family business research on socialization, and by recommending that a range of socialization forms (particularly dynamic forms) be considered when investigating continuity and succession in family businesses in the future.

Our paper, by broadening the socialization research agenda, also adds a new dimension to our understanding of transgenerational entrepreneurship in family businesses. Research on transgenerational entrepreneurship so far, has been framed by a corporate entrepreneurship and strategic management perspective, where family firms are thought to retain competitive advantage across generations by successfully transmitting a family firm's 
unique business, social and cultural resources and entrepreneurial legacy ('familiness') (Jaskiewicz et al., 2015; Barbera et al., 2018) and combining them with an entrepreneurial orientation (Habbershon and Williams 1999; Habbershon et al. 2003; Nordqvist and Zellweger, 2010; Zellweger and Sieger, 2012; Zellweger et al., 2012). Family firms who fail to pursue a positive strategic entrepreneurial orientation will tend to stagnate through "strategic simplicity and inertia" (Zellweger and Sieger, 2012: 68). The concept of entrepreneurial orientation has been taken further by combining it with the notion of 'longterm orientation', in which successful families are thought to have developed long-term strategies that account for their long-term transgenerational success (Le Breton-Miller and Miller, 2006; Lumpkin, Brigham and Moss, 2010; Lumpkin and Brigham, 2011). Both 'longterm entrepreneurial orientation' and 'entrepreneurial legacy' concepts theorize that normative socialization mechanisms exist for transferring entrepreneurial orientation, and the skills to put it into practice, from one generation to another. We suggest, however, that there are limits to how far entrepreneurship attitudes and skills can be normatively transmitted through parents and extended families in the longer term. We propose that in conditions of rapid change, shorter term and adaptive socialization processes may become more influential in driving entrepreneurial change. This constitutes our second contribution to the literature.

Jointly, these insights show the value of adopting a holistic viewpoint to shed new light on the complexities of how socialization may operate across generations in long-lived family businesses. We explain how socialization in the longue durée includes three concentric layers unfolding over time that might be variably activated and often require re-socialization, the unlearning of old values and their replacement by new ones based on agent-context interactions. Each layer of socialization is characterized by a distinct set of dimensions, values, challenges and processes. These layers are: Internal socialization where older family members transmit knowledge and values to the young family members in the context of the workplace (a process well covered in the family business literature). Interactive socialization where younger members socialize with a wide variety of stakeholders and peers, and try to resolve competing role and identity demands. Experiential socialization where younger 
family members rely on self-directed learning to make sense of shifting social, economic and business frames of reference. Where change is rapid and unpredictable, we envisage that experiential socialization will be iterative and dynamic, resulting in frequent reflective realignments of meaning, social and work perspectives, and roles and business practices. The individual experience of improvising in the face of change may provoke reassessments of other socialization influences that emanate from family socialization and peer interactions. We use a single case study of a multi-generational Scottish family firm to articulate and illustrate these three layers of socialization across generations and what happens after a round of succession occurs. This case study, we emphasize, is a platform for developing an inductive and emergent theoretical understanding. It does not pretend to provide an overall generalized theory of family business socialization. To accomplish this, we first present a historical overview of socialization theories as they developed over time, followed by the methodology deployed in the collection and analysis of our data; then discuss our findings in terms of theory and practice; and finally, offer propositions and directions for future research.

\section{Theory Overview: Socialization as Continuity, Interaction and Experience}

In the sociological literature, socialization has traditionally been associated with functionalist theories of socialization originally pioneered by Talcott Parsons (1951). Socialization is achieved by an 'internalization' process, in which learning consists of embedding social norms, roles and values into one's own mind. In Parsonian socialization, there is thus a strong prediction of continuity and transmission across generations and an objective conceptualization of time based on age - as opposed to 'generation' as 'a subjective condition of having experienced the same dominant influences" (Pilcher, 1994: 486). If the functional needs of the society remain the same, the internalization socialization process ensures its continuation.

Family business researchers have tended to follow a Parsonian functionalist perspective that stresses of the perpetuation of social values, roles and attitudes through family socialization (Jennings et al., 2014; García-Álvarez et al., 2002). Additionally, much 
family business research views the socialization process as a series of life stages of learning, in which children are purposefully inducted in the business from an early age with succession in mind, involving 'learning the ropes' and increasing participation in management (Perricone et al., 2001). This approach blends normative socialization theory with family development "life-cycle" theory (Gersick et al., 1997; Hoy and Sharma, 2010). Gersick et al.'s three dimensions of family development (the young family, working together, "passing on the baton"), is each associated with distinctive socialization processes. The early life stage concerns primary transmission of core societal values (including gender socialization) flowing primarily from the parents and then involves the wider family. At this primary stage, not only are wider societal values transmitted and reinforced, but also values and norms specific to the family culture. Secondary socialization, concerned largely with learning and establishing business roles, is linked with the introduction of younger family members into the business, engaging in a period of apprenticeship and learning to work with key stakeholders in the business (both family and employees). At the "passing of the baton" stage successors are socialized into senior management roles, ready to take over when the time comes. In this body of literature (Foster, 1995; Handler, 1990, 1994; Cabrera-Suárez et al., 2001; García-Álvarez et al., 2002; Griffeth et al., 2006), succession planning is ultimately the previous generation's responsibility, providing a basis for role adjustment and a successor's assimilation to fit the needs of the business. Here, roles are coherent even when they are periodically adjusted.

Parsonian socialization in family business research is challenged by the fact that many family businesses display poor successor motivation and failed intergenerational transfers (Handler, 1990; Cabrera-Suárez et al., 2001; Griffeth et al., 2006). Despite intensive socialization pressures from older family members, successors often do not respond to or engage in mutual role adjustment in different stages of succession (Handler, 1990, 1994; Miller et al., 2003; Cater and Justis, 2009). Jennings et al. (2014) suggest that the life-stage development model is limited, as it discounts people's social ecology, which blends socialization from within the family with that from without. Its theoretical insights thus weaken in times of radical change when the replication of good practice as a component of 
continued performance across generations becomes less relevant.

Functionalist theories of socialization have been criticized by interpretivist sociologists (Wrong, 1961; Grbich, 1990; Abrantes, 2013a; 2013b), since different influences and contexts in various phases of life (such as family, school, peers, community, work, mass media, social class) differentially affect individuals and produce conflicting responses by actors to various socialization pressures. Consequently, an alternative 'interpretivist' tradition of socialization sees socialization as a dynamic interactive process, one in which individuals negotiate their roles and positions with others, self-reflect and constantly realign their roles and expectations. In the family business succession planning literature, the influence of the interactionist lens is revealed in the use of 'family harmony' (or agreement) as a second key motive of incumbents ('continuity' being the first) (Gilding, 2010; Gilding et al., 2015), or more recently, in the use of a 'whole-person' learning approach to family business education (Barbera et al., 2015).

Conceptualizing socialization as a dynamic, interactive and adaptive process, in which individual agency plays a key part, has recently cross-fertilized with neo-Parsonian views that theorize family business succession not as a normative strategic process, but as a social exchange system, a "multiphase, multi-stakeholder process" (Daspit et al., 2016: 44). An indirect effect of this theoretical development is that the entrepreneurial individuals' learning history is now understood as lifelong dynamic accumulation (Cope, 2005) in which selfknowledge is derived from social interaction with multiple sources (Swann et al., 2009). The relevance of social context (home, education, workplace) in understanding how entrepreneurs learn managerial tasks from observing role models (Zozimo et al., 2017) or how family business members learn unevenly about continuity through social situations (Konopaski et al., 2015) is stressed in this perspective. This is a dynamic perspective embracing the external context in which learning is situated and accommodating a potentially expanding number of family and non-family stakeholders.

Viewing socialization as a process of replication (internalization) on the one extreme, and of constant dynamic re-alignment (interaction) on the other, reproduces the idea that learning is inherently socially constructed (either functionally or interactively). We argue here 
that there is a third option in how to approach socialization and its learning outcomes (Jones, 1983) that understands family business succession as inextricably linked with the individual actor's ability to influence external conditions and the personal experiences that $\mathrm{s} / \mathrm{he}$ has accumulated over their lifetime. In the case of socializing post-industrial family business successors, this learning is not just objectively received by organizational membership or interactively shared as an organizational identity through negotiation (Zellweger et al., 2010), but also mediated by personal experiences accumulated through the successor's individual life journey. Such personal experiences enable individuation in norms and are associated with different degrees of individual agency and different levels (individual, interpersonal and group) of attachment to role expectations. It is suggested here that the socialization of family business successors cannot be adequately explained without addressing the temporality of their contextualized experiences and biographically determined cognition across family boundaries.

Re-socialization is largely understood as the "replication of socialization processes" when individuals "join another gathering or when life circumstances change" (Bhatnagar, 2015: 1), "re-enter a social structure" (Ladge and Greenberg, 2015: 980), and often relates to an effort towards "disrupting taken-for-granted cultural assumptions" which modify an individual's identity (Jones, 1983: 471). In sociology, re-socialization has been researched in a variety of contexts, from re-socializing criminals to prepare them for release, to the resocialization of immigrants to help them find their place into the host country (McCorkle and Korn, 1954; Bar-Yosef, 1968; White et al., 2008). Furthermore, social disintegration has been presented as a prerequisite of re-socialization "because in re-socialization the person adopts values which are based on an interpersonal order and potentially contradictory to the old ones binding the collectivity" (McHugh, 1966: 357).

In organization studies, employees are seen to "experience many re-socialization processes throughout their tenure, as their role and the organization changes" (Hart et al., 2003: 492). In these studies of corporate businesses experiencing and implementing change, it is the external changes that provoke organization leaders to change systems and working 
cultures. Employees must unlearn the old and replace it with the new. Such re-socialization also happens when employees' own self-concept has independently altered, as in the case of working mothers (Ladge and Greenberg, 2015). In the family business organization, however, it is not just the workforce that can require re-learning and re-socialization, but the family itself. Family business leaders brought up in a tradition of stewardship and continuity, in the perpetuation of a long-established family culture and business system, are often slow and reluctant in recognising change and taking steps to embrace it (Salvato et al., 2010). In these circumstances, wider external forces may invite the re-socialization of not just the successors, but also of the older generation. This reflects the growing view in psychology, of reverse or bidirectional socialization, with the children's ability to modify the beliefs and values of their parents being emphasized (Grusec, 2011). Overall, the re-socialization concept offers a contextualized explanation regarding "the simultaneous operation of multiple interaction effects" (Welch et al., 2011: 756) and as such, is characterized by non-codified transitions, discontinuity, questioning, confusion, and reorientation.

In this paper, we thus propose that the extent and nature of socialization processes in family firms differ according to the requirements and pressures of contextual external conditions which underpin successors' personal experiences. Sociological theories on socialization have identified different forms of socialization which are not necessarily mutually exclusive, and which interact or conflict in different ways according to context. We have distinguished three layers particularly relevant to family business socialization, which we termed 'internal, interactive and experiential' socialization layers. Only the first of these has been explored in depth by family business researchers. How interpretivist forms of socialization occur and relate to each other is an open question, which requires empirical research to develop further understanding. Our empirical research, though limited, represents a start. In an in-depth single case study of a four generational Scottish family construction firm, we explore how entrepreneurial socialization emerges (or not), how it is affected by peer pressures and context, and under what conditions those socialized influence the values of those who attempt to socialize them as they acquire new ways of thinking. Both functionalist 
and interpretivist views of socialization shed insights on these socialization processes during different periods.

\section{METHODOLOGY}

The multi-layered socialization processes discussed above are explored empirically in an indepth qualitative single case study of a Scottish family business, the McKay and Mills Construction Company. The use of case studies is a well-established methodological approach in the social and business sciences (Eisenhardt, 1989; Eisenhardt and Graebner, 2007; Yin, 2009; Baxter and Jack, 2008). Eisenhardt and Graebner (2007: 23) explain that "building theory from case studies is a research strategy that involves using one or more cases to create theoretical constructs, propositions and/or mid-range theory from case-based empirical evidence ... by taking advantage of rich empirical data". The inductive generation of theory is but one of three advantages of employing a qualitative case approach (Siggelkow, 2007). It can also be employed to "sharpen existing theory by pointing to gaps and beginning to fill them" (ibid: 21) or even to employ cases as illustration to clarify constructs. Such inductive research can provide a better theoretical platform for subsequent deductive testing of theoretical propositions and hypotheses using quantitative methods.

The adoption here of a case study approach is justified by the need to progress theoretical understanding of how socialization operates in long-lived family firms. There are other qualitative approaches such as grounded theory and ethnography which yield even richer data and are perhaps more appropriate to theory generation when little is known about a phenomenon, but applying these methods is impractical when gathering data on past events, sometimes going back a whole generation or more. One cannot observe the past retrospectively through participant observation, for example, when the events being researched precede the researcher's existence. Thus a case study approach as adopted here, which explores phenomena through in-depth interviews involving past recollections, and triangulated through a variety of interview and secondary sources, is the most practical qualitative approach.

A fundamental decision of case research is whether to adopt a single or a multiple 
case strategy (Yin, 2009). Our decision to take a single-case approach allows for more intense and contextual analysis of a phenomenon, and is particularly useful when relatively little is known about a complex phenomenon or when complex dynamic processes are operating (Dyer and Wilkins, 1991). Siggelkow (2007) addresses the common criticism levelled against a single case study that it lacks representativeness or generalizability. He states that "it is often desirable to choose a particular organization precisely because it is very special in the sense of allowing one to gain certain insights that other organizations would not be able to provide" (Siggelkow, 2007: 20). The McKay and Mills case was thus purposefully selected as a revelatory and clear example of a multiple family business succession that illustrates different forms of socialization as external conditions change. Its uniqueness offers variety and "opportunity to learn" and refine knowledge rather than representativeness (Stake, 1994: 243).

Multiple case studies permit comparisons and the analysis of similarities and differences between cases. This enables a more general, reliable and, potentially, a more convincing level of theorization (Eisenhardt and Graebner, 2007). However, researching multiple cases is a time-consuming and expensive process (Baxter and Jack, 1998) and there is thus an inevitable compromise to be made between depth and coverage. The more cases there are, the better the representativeness, but the less time there is to devote to the study of any single case (Gerring, 2004). In practice, the adoption of a multiple case approach is most advantageous when enough theoretical progress has been made through the adoption of more in-depth approaches (Eisenhardt, 1991). In the current paper, the paucity of previous research on how interpretivist forms of socialization operate in family businesses suggests that a single case approach is more appropriate at this stage of knowledge.

\section{Implementing the single case design}

The McKay case was conducted as part of the worldwide STEP (Successful Transgenerational Entrepreneurship Practices) research project, investigating transgenerational entrepreneurship in larger family firms. The case conformed to the original STEP case study selection criteria of being multi-generational, with majority family 
ownership and control, of a large size (greater than $£ 8 \mathrm{M}$ sales turnover) and showing evidence of entrepreneurial activism and high-performance outcomes. A central aspect of the research was to investigate, through multiple qualitative interviews of family and non-family members, how entrepreneurial family values and resources emerged or were transmitted from the founders to subsequent generations (Habbershon et al., 2003).

A total of six life history interviews were conducted by the first author with key strategically relevant actors, such as family and non-family members of the McKay and Mills house building company in Scotland (see also the McKay family tree in Figure 1). Questions about specific strategic choices, activities and processes were asked (Table 1) and answers were sought from informants who were open to reflection. An important part of the interview guide used for the STEP project asks about the historical development of the family business with a focus on the family members' role and involvement in the face of environmental forces, their values, competencies, experiences and networks across generations and how these relate to the challenges of successions. Interview questions covered five topics: background information on key actors in business and family; history and externalities; entrepreneurial orientation; familiness resource pools; and entrepreneurial performance.

The STEP interview guide was not originally designed to explore socialization in family firms specifically (Table 1), but socialization was an important element of the overall transgenerational transmission process of values and practices. There is an implicit assumption in the STEP model that socialization is a normative internalization process, with a strong role played by parents and founders in establishing core values and practices (Nordqvist and Zellweger, 2010). Thus, there was no specific attention paid to the possible interaction of adaptive or dynamic forms of socialization and re-socialization. However, through conducting in-depth interviews, the guide's transgenerational lens helped us to inductively derive insights on how and why different kinds of socialization fit different family leadership succession contexts from generation to generation. It was the extensive representation of socialization processes in our in-depth interviews that led us to review the relevant sociological literature.

Of the six people who were interviewed, four were family members and two were 
non-family members (Table 2). The inclusion of non-family members provided new information and perspectives that family members either were less aware of, tended to gloss over or ignore. This enhanced the triangulation effects of having multiple respondents commenting on the evolution of socialization processes in the family case. All six interviews were transcribed verbatim, lasted 50 to 100 minutes and were with company directors or managers (Table 2).

Secondary data sources were used (Table 3) to construct the owner-family profile (including interview transcripts of deceased generations), map out entrepreneurial moves, describe important contingencies (e.g. industry, tax regime and environment), understand the family business governance structure, document relevant outcomes (e.g. profits) and accomplish triangulation (Zellweger and Sieger, 2012). At this stage, both the second and third authors were kept out of the field altogether by exclusively assigning them the role of resident devil's advocate (Sutton and Callahan, 1987), a decision which became even more important given that the logic of replication could not be employed in the single case study analysis.

INSERT TABLE 1, 2, 3 and FIGURE 1 HERE

\section{Data Analysis}

The research focus on socialization and re-socialization emerged after the data analysis had begun and involved an iterative process of re-evaluation and assessment of "the 'why' of what is happening" in a multiple family business succession (Eisenhardt, 1989: 542). To this end, a line-by-line analysis (taking pairs of expressions, searching for similarities and differences, and cutting and sorting) rather than a word count was opted for. Figure 2 shows our data structure (including first-order codes from the case, theoretical groupings of our initial codes that had emerged from the case, and the aggregate theoretical perspective) (Walsh and Bartunek, 2011; Kotlar and De Massis, 2013). Data analysis involved three 'passes' through the data:

In a 'first pass' as per the interview guide, the STEP model components ('entrepreneurial orientation', 'familiness' and 'entrepreneurial performance') for 
transgenerational entrepreneurship were used to outline key points raised by each respondent and place all the evidence within each such component (Yin, 2009). This was followed by 'open coding' using a matrix of five first-order categories ('transgenerational intent', 'childhood experience', 'value transmission', 'points of organizational entry' and 'role acquisition') based on prior theoretical understanding of socialization as an incremental process. This created in-depth descriptions for key theoretical sub-themes (socialization $=>$ social identification ('I am') => internalization ('I believe') encountered in the social identity literature (Ashforth and Mael, 1989), but now applied in the family business context. As Ryan and Bernards emphasize (2003: 93), "this tactic - marking obvious themes early and quickly - forces the search for new and less obvious themes in the second pass". It also revealed the contrasting perspectives of stakeholders and produced a re-contextualization (a redescription) of different rounds of family business succession and their socialization processes (Welch et al., 2011).

In a 'second pass' through the data ('axial coding'), it became apparent that the presence of an independent variable such as 'socialization' did not preclude the interference of an intermediary mechanism ('re-socialization') for successful transgenerational social identification (socialization $=>$ re-socializing experience $=>$ identification $=>$ internalization). Here the authors analyzed the wide range of external agents and stakeholders (Table 4 and Table 5) underpinning the unique dynamics of re-socialization to delineate how this makes the process different from what the internal socialization literature suggests and why additional layers of socialization (interactive and experiential) may be activated. These layers of socialization became our second-order theoretical groupings of the first-order codes that had emerged from our case. We went back and re-coded the case study data to match the emerging theoretical layers of socialization with second-order codes. At this time, internal 'peer debriefing' (by all three authors) in the sense of challenging the first- and second-order socialization categories and sub-themes, and addressing potential for bias, was also used.

In a 'third pass' through the data, we worked on teasing out a narrative strategy to explain why socialization processes change in the longue durée in terms of an overarching theory of socialization in family firms and gain understanding of the temporal order of the 
second-order categories (three layers of socialization) previously identified (Figure 2). In this data analysis context, the presentation of the single case study data below, "consists of a narrative that is interspersed with quotations from key informants and other supporting evidence" (Eisenhardt and Graebner, 2007: 29) and constant comparisons "between an empirically based pattern with a predicted one" (Yin, 2009: 136).

INSERT TABLE 4, 5 and FIGURE 2 HERE

\section{FINDINGS}

\section{McKay and Mills Construction and the McKay Family}

McKay and Mills Construction Ltd (M\&M) was established in 1925 as a result of the two founders' eagerness to exploit subsidies of private house building offered by Scottish local authorities following WWI. The founders had previously established separate ventures involving renting and small-scale house building. By 1932, the firm was employing 2,000 workers on its sites in Scotland, and had established reserve land holdings for future development in the trust of their wives. The firm experienced several cycles of opportunity and decline in the 1930s in housing construction and letting. Construction of private housing ceased in WW2 and they turned to war construction projects to survive. They returned to their core business after the war.

By 1947, one of the founding families, the Mills, severed their connection with the company leaving the McKays as sole owners. After the war, they continued building traditional housing as demand recovered, but in the 1960s, their ability to grow was stifled by the death of one of the family owners, and the need to pay large death duties. During the 1970s, a period of inflation and instability was followed by two severe recessions, as the Scottish economy was restructured in the face of global competition and increasing labour disturbances. Moreover, the construction industry was subjected to mechanization of site operation and new and complex planning restrictions. This volatile environment led to a restructuring of building methods and assets, and the family managed to struggle through without having to sell the firm. They were one of the few pre-war construction firms in Scotland to survive the 1970 s. 
M\&M experienced two more severe recessions in the 1980s and 1990s and this forced them to begin to diversify and make significant changes to their long-established family business model. By the 2000s, M\&M was reported to employ up to 300 people. It retained significant family involvement in its top management, but had also learnt how to improve performance, run autonomously and be managed efficiently with the help of corporate methods of operation, bank finance and home-grown professional managers. An increase in the number of shareholders (up to 30) also facilitated a process of reinvestment. M\&M Group was set up as a new holding company with majority family ownership and control in 2008 in response to emerging modernization and succession planning issues and a new growth strategy. The business environment became less externally given (e.g. through subsidies, inflation, recession, taxation reforms and labour troubles) and more flexible (e.g. through digital technologies, sustainable construction innovations, quality accreditations, skills gap, health and safety regulations) (Table 5).

\section{First round of family business succession: Socialization via family apprenticeship}

The family business is in its fourth generation of owners (Figure 1). The original founder, Anthony McKay, was an authoritarian figure typical of a generation who were born in the late Victorian era. By the 1930s, his two sons, Frederick and Donald, had begun to work in the family business and assume roles of managerial responsibility. Donald emerged more strongly as the overall strategist in the 1950 s as his father began to step back. His brother, Frederick, was more hands-on and closely oversaw every day construction. Donald McKay became the sole family leader after Frederick died in 1961 soon followed by his father, Anthony in 1962. The first round of succession (Donald's) was thus a prolonged affair (from the late 1930s to the 1960s), and it involved gradual transfer of knowledge, values and responsibility from the older to the younger generation.

We have no first-hand records of the socialization experiences of the earliest generations of the McKay family, but we can assume that they were rooted in repetitive task based 'on-the-job' learning over a long period of time, in which new responsibilities were gradually added. At the same time, they would have been heavily influenced by the Christian 
protestant values of prudence, hard work, self-reliance and paternalism that prevailed in Victorian Scotland. The family founder, Anthony McKay, grew up as an apprentice in his father's carpentry and construction business, and learnt the house building trade from the bottom up. By the time he ventured into large-scale house building and property letting through establishing M\&M, he had learnt how to exploit new opportunities in a positive but careful manner.

He established his family business based on building low density but quality small and medium scale housing, supported by prudent acquisition of rental properties and land for future building expansion. This model was followed without major changes until the 1990s when his son Donald died. It is evident that long exposure to Anthony's (the founder's) leadership of the family was the major influence in fully socializing Donald into core business and family values ("Donald started at the bottom, not quite digging the holes on a building site but working as the lowest level of manager", Bill McKay). His long apprenticeship, managing the company at increasing levels of responsibility, gave him a personal understanding of the detailed production and administrative practices of the firm, and with his brother Frederick, he was able to take "a very hands-on" approach in controlling the quality of work.

We have the recollections of the third-generation successors, David and Bill, to testify to the kind of organization into which their second generation fathers Donald and Frederick were socialized. David explained that the $20^{\text {th }}$ century M\&M management structure resembled "a clan": there was one at the top and then there were all the others, there was no sort of grades as such it just seemed to be that everyone was below the chairman and that was it". M\&M in the 1930s was an organization whose founder Anthony McKay liked to be addressed as 'Colonel' in all his business dealings in accordance with the rank he achieved during his military service. As David (third generation) remembers, "they tended to be much more dictatorial" and family business management revolved around the 'bullying will' of its head. In the 1930s, Donald was claiming in the Company's History book (1999) that "we have to have a firm proper organization otherwise we would be in a state of chaos".

David highlighted the company's ruthless ways of dealing with mistakes on building 
sites: "in those days you just used to fire them, you can't do that now because ... you've got to go through the system and so on”. This was a hands-on leadership aimed to ensure a tight control of the building process: "we didn't have such defined roles in that era" (Bill), "there were no management meetings" (Alan) and "everybody got the same pay increase" (Alfred). Strategic decisions such as that of creating a separate manufacturing firm (1966) was a response to given tax exemption incentives rather than a new way of organizing business activity. Strategy was rarely discussed or planned formally as "they were so busy working and never talked; it was just head down" (David McKay).

Socialization during the first round of family business succession can be defined as 'internal' where older family members transmit values and knowledge to younger members through on-the-job learning. There is very little questioning, since younger generations focus on internalizing family business values such as obedience and harmony. The Scottish housing industry experienced several major booms and recessions in this period, yet construction techniques were slow to change and relied on tested traditional building and managerial methods that went together with an authoritarian top down management. We conclude that when change is slow, family leaders favour strategies of normative socialization, younger family members experience similar gradual induction into the business to those of others in the same industry, whilst peer networking tends to reinforce rather than challenge internal socialization.

\section{Second round of family business succession: Socialization conflicts and adaptation}

In the 1960s and 70s the third-generation cousins, David son of Frederick, and Bill son of Donald, joined the family firm and began to assume managerial responsibilities. At this time, Donald, as family leader, was beset by problems of the 1970s and 1980s recessions, and their ability to assume responsibilities under him was delayed by the emergence of a non-family board member who was largely responsible for the survival of the company at that time. Donald's socialization experience had not equipped him for the changed conditions and he resolved this by recruiting externally the financial skills needed to restructure the company. The third generation jointly took over the firm in 1993 when Donald died. By this time, the 
participation of non-family members in the management of M\&M was firmly established. The second round of succession, therefore (that of David and Bill from Donald) involved a shorter period and a greater transition of responsibility than that of the first and had to adapt to much more volatile economic conditions than their fathers had faced. There was an accelerating change in building and managerial practice during this period.

David stresses that nobody forced him to join the family business and it was more of a 'natural' development: 'I'd worked as an architect in an architectural practice, and then I started in town planning, and my father died suddenly, and I had to come into the office". Similarly, Bill McKay stressed the inevitability of joining the firm. "I just say to people I was born with brick dust in my veins, so I have no choice". There was an expectation to join the business for family members whose motivation to join was originally engineered through an internalization process, as Bill vividly remembers:

"So I was a very young man working in this smart architectural practice and if things went wrong on a site I was often sent to sort it out and I'd say why are you sending me I can't do it, why me, oh you understand these people they would say and then I thought well I'm one of them that's why so".

In an organization where promotions were "all just done by a nod and a wink" (David), the female successor's experience was even more so normatively moulded three decades ago, as Bill's daughter, Mary illustrates:

"My aunt was a secretary and stayed for a year or two and that was it, because she didn't see that she was going to have any future and I think she wasn't going to be encouraged, she knew she was going to be held back so she left ... and got married".

Bill, another architect, gives a detailed account of how he was brought up and mentored throughout his working life by his father Donald McKay. The importance of inculcating self-reliance and learning by doing was a central feature of his style:

"If I went in and had an idea and wanted to discuss it, my father would say just do it, tell me how successful you think it's been"

"If I made a decision that wasn't right on site Donald would go quietly to the site and speak to the site manager and say now this is what I want to do, you must never tell my son that I told you this and you must never tell the guys on the site why we're doing it"

For such members of the older generation, succession brought a passage to a new position in the career ladder (task-based learning), but not to a new organizational culture 
(interactive learning from others): In this environment, male successors were expected when sufficiently socialized, to push for directorships as a continuation of their ascribed role. According to Bill, his father's leadership style revolved around instructing his successors from a distance and thus stressing issues such as "I don't want you to talk me through your thinking, you've been trained to think so show me the results". Bill continues that directorships were perceived in a different way then, "if you were in it you were the boss if you weren't you weren't it. I think we make it more of a journey now", whereas "shareholders who didn't work for the company were not highly regarded". As David explains about the past situation, Donald held information close to his chest "it used to be all hidden away and (third generation) shareholders had to sort of prod my uncle Donald you know to give them information" and the influences of peer interaction were avoided.

Faced with Donald's traditional paternalistic and authoritarian style the reasonable solution of competing role demands for the third-generation family business successors was to avoid being “very hands-on the day-to-day running of the business, they'd sort of divorced themselves from that side of it" as the current CEO (Ethan) adds. In this business environment, the personal management of ineffective generational encounters for those who have now qualified as talented architects was achieved by geographical separation rather than intergenerational conflict. As Bill admits, "until my father Donald died or got very frail, I didn't come a lot to Glasgow I just ran the Edinburgh branch".

As a result, the two cousins' interactive re-learning was largely intra-generational and based on open-ended and life-long interactions with other architects and peers. Under the influence of Scottish Modernist housing design "that opposed repetitive mass housing and instead called for 'vernacular' patterns" younger family members advanced design-based innovation as a result of their interactions with educational networks, mentors, industry networks, peers, and other social or professional groups (Table 4). This set the company "apart from other Scottish speculative builders in its sensitivity to advanced housing design trends" (Company's History Book, 1999). Failures of the internalization schema and increasingly irreconcilable identity conflicts found an organizational resolution when Jack, a non-family director, slowly ascended the management ladder to become the top decision 
maker in the post-1970s because the family successors (David and Bill) were not considered by Donald McKay to have enough business acumen and values to run the company on their own. "Rather than pass it to a family member the Chairmanship for the first time went out the family to Jack, the financial director who ran the business with Donald's son and nephew reporting to him" and was "more cost-aware ... looking at these other competitors" and heavily involved in national politics (Ethan).

Following Donald's death in 1993, David and Bill as the third-generation successors now led the company in a more hands-off but also egalitarian and collaborative leadership style, empowering people around them, learning from peer pressure, listening to the views and opinions of diverse stakeholders (Table 4), and adapting to their business environment that included powerful non-family directors. The traditional values of obedience, loyalty and harmony and the internal socialization processes that underpinned them were increasingly being challenged by changing social and economic conditions that moved successors away from spending much time with the firm.

When Donald lost faith in the third generation's ability to take over and hired a nonfamily manager to run the company, this increased the opportunity of the successors to engage in 'interactive socialization' where younger family members and non-family actors navigated multiple perspectives as they interacted with a range of stakeholders. This period is characterized by a lot of doubt and uncertainty, fractured values, divergent expectations, as well as competing role and identity demands. During the second round of family business succession, socialization processes have become more egalitarian and adaptive, as stakeholder views and peer pressure have become more salient. We conclude, therefore, that when change is moving faster than perceived by family leaders, divergent business cultures emerge, additional normative socialization leads to conflicts and interactive forms of peer and professional socialization become more relevant.

\section{Third round of family business succession: re-socialization and iterative change}

A fourth generation, Alan, Mary and Rob, began to involve themselves in the company after 2000. The McKay Group's Board of Directors was then proactively expanded to allow the 
entrance of fourth generation successors and to ensure family control over the strategic decision-making, but at the same time, allow operational managers to run all subsidiary companies. The third round of succession is now under way and its socialization practices once again emerge as substantially different. The task learning approach achieved by exposing children to the family firm from an early age had been substantially relaxed. Alan McKay (fourth generation) remembers his childhood including only occasional visits "to the office to meet my father David sometimes at the end of his working day or lunch or something with mum”. His experience was rather dominated by a grid of non-familial public forces and across family boundaries e.g. "as a child in (a private) school locally, I could never get away from the fact that I was involved or related to 'the family company' which was an interest within the local community". Bill's daughter Mary also recollects how her mum would not allow "business talk around the table, so we didn't know what was going on in the business". She also emphasised the lack of regular on-site task-based training for all family business successors:

"I was never asked to help out and my father never brought us in there to show us what was going on, it was normally just if we needed to get dropped off or taken home ... we were never pushed into it".

Alan's ascendancy to leadership (aged 28) is distinctive. After finishing a UCL graduate/postgraduate degree and working in a London surveying practice for a few years, he first joined the family business as the Assistant Land and Planning Manager "so it was pretty low on the pecking order ... I had to learn about the history of the company properly and also the different sites that we had through the (planning permission) systems ... I was promoted every two or three years". His current position within the company was therefore an independent professional choice that required moral justification "personally I feel that I have to be seen to be in very early in the morning and almost last to leave" provided that his work peers' opinion was as important as that of his family members. Since his arrival in 2000, the adoption of a modernization' strategy amounting to a series of everyday business life readjustments and collaborative problem-solving has taken prominence in an ambiguous and complex external socio-economic environment (Table 5). All generations were involved in the process of competitive strategy, and value creation was delivered through constant 
iteration with a turbulent wider environment. For example:

"The older generation has got to learn to appreciate it. They know if the company is going to grow in this quite aggressive doubling of units and profit increases, it cannot stand at the traditional quiet pedestrian pace where it becomes like a hobby. If it is going to become faster and a bigger business, it has to react more" (Alan McKay).

In this new context, family socialization neither guaranteed consensus nor did generational encounters appear to influence the process of entrepreneurial self-identification and family business values are no longer used by actors to describe themselves. It is rather the 'understandings of the self' in its experiences of fast decision-making and interaction with the shifting external context that now reshapes family business values. Socialization processes of family members entail iterative changes and shuffling in an endless quest to reconstruct, repair, or revise their social and business selves and how they relate to others during times of relentless changes (e.g. bank and land deals; employee appraisal shareholder liaison group; 'Investors in People' and ISO accreditations; carbon footprint; customer service; share equity incentives; purchase assistance plans; social media and community involvement) (Table 5). Recognizing the inadequacy of previous family attitudes and business practices, younger family members now pursue opportunities based on their own experiences and in self-directed learning: "I was keen on doing my own thing ... and just try and become my own person", (Alan). As the need for managerial and entrepreneurial professionalism increase in a malleable environment, re-socialization becomes more dominant in shaping strategies and decisions and involves a dynamic mixture of everyday conversations, emotional encounters, role transitions and sense-making efforts in and out of the family business context. As Alan McKay states:

"We don't have to wait until the next board meeting to make a decision like that; we could do it within an hour; the culture has become more and more open every year"

The need to re-socialize different generational shareholders experiencing role discontinuity was also explained by the older generation. As Bill McKay grumbles, "I take things that other people want me to do now - before I just took things that I wanted to do" demonstrating that the re-socialization process now takes place both intra- and intergenerationally. The older generation had to re-enter the same organizational role and now 
reconfigure it: "you've got to be aggressive nowadays; you can't just sit back and let things happen because you'd fall by the wayside", (David). This went together with a new willingness in both the older and younger generations to compromise the firm's longstanding commitment to produce traditional style housing that was the result of adaptation to peer architectural influence ('irregular vernacular' patterns' vs. 'rows of tacky little boxes', Company History Book, 1999). Diversifications (e.g. new timber kit company, letting properties, lending money to other developers, joint venture projects) and new building methods and materials have now been employed: "we are looking to double our size, to do that we have either got to be having more sites on the go at any one time ... or to build quicker (using) timber kits", (Alan).

Re-socialization has also become a conscious strategy in the business. A fast moving board of family and non-family directors, a less self-sufficient growth strategy, a proactive approach to the formal and informal creation of entrepreneurial opportunities in a malleable context (e.g. the new induction and other tailored programmes for apprentices) and adoption of new 'modern' managerial practices (e.g. new open plan offices) are among a raft of recent changes that have reversed years of more traditional family management practices. This is best illustrated by attempts to involve shareholders more in the running of the company, requiring many to reconsider and abandon older cherished assumptions. To facilitate this, a range of fair exit mechanisms (e.g. market value payment for shares of 'Good Leavers') for those shareholders who may get disorientated, lost in self-doubt and refuse to participate in the re-socialization process was devised in 2008. Moreover, a biannual shareholder liaison group meeting was launched to address the challenge of how to "make minority shareholders feel involved and listened to", whilst the balanced shareholding ("so one cousin's family can't overdo the next lot", Alan) often caused vertigo by the constant need for iterative change and sense-making. Moreover, the latest generations of McKay's not only have experienced re-socialization themselves, but have also used it as a means to realign the attitudes and practices of more conservative employees: "they had desks that were very high with storage up here so that there was no interaction, and every department worked as a kind of different silo ... but now spontaneous meetings take place in the open plan office" (Alan). 
At the same time, the stress on managerial professionalism has also questioned the traditional assumption that succession should be through family members. As the finance director, Alfred (who joined in 2005, previously being a partner in KPMG) emphasizes: "they don't see each other on a family basis very much at all”; Alan adds that successors were now welcome only "if they proved that they had something (skills) to bring and if the managers at that time driving the company forward felt likewise". Such re-socialization process was stressful and intermittent, included both formal and informal elements and often lacked continuity, but nevertheless accumulated over time in new corporate structures (e.g. toolbox talks on site and suggestion boxes, on-site appraisals and a performance-related bonus scheme) (Table 5) and enabled both family and non-family actors. The current non-family leader Ethan appointed Director in 2002 and CEO in 2004 started working-life within the firm as an apprentice painter (aged 15). His managerial ascendance reflected his ability to build trust ("both (family) sides have great faith in him", Alfred)" and orchestrate the resocialization process ("I can lift the phone to pretty much everyone of those shareholders; they will all talk to me on a very personal basis", Ethan).

There has also been a dramatic shift in the family attitudes to and by female family members and their roles. Mary, who joined the family business in 2002, has been the first female to claim a place in the top management tier. She wanted to follow her father into the business because it was "a more exciting world than being a housewife" which she felt was a role not held in the high esteem that it was in her mother's day. However, she also felt her entry had to be earned on merit, and she achieved this by working for a period in an advertising agency not connected with the family firm. As the family firm had no marketing position, she was able to use her experience to negotiate a new senior role as a marketing specialist within the firm.

Socialization during the third round of family business succession period can thus be characterized as 'experiential socialization' where all family members and firm actors address the need to respond quickly and innovatively to changing social and economic conditions affecting their family and business. In the M\&M case, the fourth-generation experienced challenges of ambiguity, disorientation, and complexity, role interpretation and sense making. 
In partnership with non-family members, they engaged in a series of emergent strategies to cope with changes including self-directed learning, critical reflection, constant questioning, iteration, and resilience. Re-socialization was an important social conversion mechanism for re-orientating their values and strategies to new models of best practice within their industry.

\section{DISCUSSION AND CONCLUSION}

\section{Implications for theory}

This paper has broadened existing research on socialization in family firms in three ways. First, it has broadened the unit of analysis for conceptualising socialization from a one generation to a multiple generational perspective. Instead of just focusing on socialization processes in a specific succession period (e.g. Foster, 1995; Handler, 1990; 1994; GarcíaÁlvarez et al., 2002; Dyck et al., 2002; Miller, et al., 2003; Griffeth et al., 2006), the paper has explored how socialization operates trans-generationally and differentially over different succession periods.

Second, it has broadened the theoretical research agenda on family business socialization by considering interpretivist as well as normative forms of socialization. The McKay and Mills case has illustrated how a different form of socialization has predominated at different periods of the family business's history. Internal socialization represents a traditional task-based approach in which the family and its leaders strategically embed core family and business values through an early exposure of potential successors to working in the business, and gradually promoting them into increasing levels of managerial control and responsibility. This was the primary mechanism for inducting the first successors. Interactive socialization, a process in which successors are heavily influenced by networking and interaction with peers and non-family corporate professionals, became increasingly in evidence from the 1970s. Experiential socialization, in which ideas, attitudes and practices iteratively change as new challenges and opportunities are encountered, became dominant 
after 2000, and has been most influential for the latest generation of family successors. An important conversion mechanism associated with interactive and experiential socialization is re-socialization, the unlearning of previous attitudes, goals and practices to permit the adoption of new ones. The latest McKay generations have experienced re-socialization themselves and have completely reversed the family culture and practices of its early generation leaders. They have also used it as a proactive strategy to realign the attitudes and practices of more conservative family shareholders and employees.

Third, it has also broadened the research agenda by demonstrating that the choice of different forms of socialization is not dependent on internal family strategic preferences, but rather on the influence and pressures of wider social and economic forces affecting the family and the business. Indeed, in certain circumstances, attitudes and skills of the older generation, conscientiously passed on to their children, may be active contributors to business failure.

Fourth, the analysis suggests that different forms of socialization are not totally independent but overlap and interact. Each layer builds on the prior one(s) that are foundational but brings in an additional layer of complexity to the mix. The third layer (experiential socialization), therefore, already involves elements from the first two layers (internal and interactive socialization). Older family members might still be playing a key role in socializing through value transmission, or younger members might still be interacting with a diverse range of stakeholders to identify their strategies. Most importantly, what differentiates the third layer is the sheer volume of everyday change and disruption posed by a flexible changing context as well as the intensity of movement, shuffling, and innovation that organizational actors experience (through sensing, feeling, reacting, interpreting, reflecting, and linking - Morris et al., 2012).

\section{INSERT FIGURE 3 HERE}

This suggests a theoretical model based on three concentric and overlapping layers of 
socialization (internal, interactive, experiential), each characterized by different forms unfolding over time (Figure 3), with re-socialization acting as a conversion mechanism for realigning values and practices from one layer to another. Our model does not address or advocate fixing and naming family business roles (e.g. family owner, CEO, board member etc.), but rather conceptualizes roles as non-stable, fluid and flexible - since family members need to constantly navigate across these roles depending on emergent environmental or organizational demands. In the first layer, the family leaders have a primary role in determining the transmission of values, roles and practices. Peers and external stakeholders become increasingly influential in the second layer and innovative learning through role improvisation and iterative change adds an important new dimension in the third layer. All three layers are interdependent, but the relevance and priority given to each form of socialization depends on the wider socio-environmental context. Hence, from this theorization, following from our data structure and findings (Figure 2), we offer specific propositions to reflect each distinct layer of our model (Figure 3).

Proposition 1 Internal Socialization (P1): Value transmission within the family, is the foundation of succession dynamics but not their lever in a transgenerational family business context.

Proposition 2 Interactive Socialization (P2): Younger generation members involved in family business succession have a wider repertoire of peer social groups other than family and the business that they refer to and borrow entrepreneurial ideas from.

Proposition 3 Experiential Socialization (P3): Socialization processes shift over time not only as both the firm and family change across generations, but also in response to how malleable is the greater external context in which successors are embedded.

Looking at our model of multi-layered socialization processes in the longue durée, we 
also offer a set of general propositions for future investigation and refinement:

General Proposition 1 (GP1): Different forms of internal, interactive and experiential socialization co-exist in all long-lived family businesses.

General Proposition 2 (GP2): The form of socialization that predominates depends on the demands of the external cultural and business environment.

(GP2a) Where cultural values and proved production systems change slowly, internal socialization will predominate;

(GP2b) Where traditional family management and practices are no longer productive through changing conditions, and there is a need to professionalize the business, interactive peer-based socialization becomes predominant;

(GP2c) Where change is driven by innovation and new markets, an entrepreneurial approach is required, involving the adoption of experiential forms of socialization.

General Proposition 3 (GP3): Where interactive and experiential forms of socialization become adopted, a period of re-socialization of old traditional values and practices is necessary.

General Proposition 4 (GP4): 'One size does not fit all'. The balance and predominance of different layers of socialization will vary considerably according to local, regional, social, economic and industrial conditions in which a family business operates.

This theoretical model has special implications to the way the transgenerational entrepreneurship is theorized. The transgenerational entrepreneurship literature is based on the idea that the potential of a family firm to continue to create new streams of value is through establishing long-term entrepreneurial orientation, legacy and 'familiness' resource pools (that embrace the external environment) as a vital element in long term performance (Alvarez and Busenitz 2001; Habbershon and Williams, 1999; Zellweger and Seiger, 2012; Rau, 2014; Jaskiewicz et al., 2015; Barbera et al., 2018). In this literature, the transmission of entrepreneurial orientation, values and practices is predominantly viewed as a normative 
internalized process through the generations (Nordqvist et al., 2013). Scholars have only exceptionally observed that entrepreneurial orientation and familiness vary dynamically over time and from one cultural context to another in long-lived family firms (Zellweger and Sieger, 2012; Basco et al. 2018). Our case reinforces this view by illustrating that an entrepreneurial orientation and culture (here captured in stories, experiences and discourses) may not be present throughout the life of the family business. Rather, the nature of the business, how it is managed and what family culture prevails may be related to external conditions and the extent to which these are pliable in the hands of different generations. This opens up the question of how successful families acquire entrepreneurial values and practices without long-term transmission of such values from one generation to another. The processes of interactive, experiential socialization and re-socialization provide a theoretical basis for answering this question. While an entrepreneurial mindset can be 'nurtured' - that is gradually developed over time, or 'transmitted' through normative socialization processes, it can also be nurtured organically through peer interaction and experiential learning. In this sense 'nurturing' is a more organic and broader term reflecting individual agency as well as inheritance.

To conclude, our study has shown that there are resource differences not only among families and businesses (Jaskiewicz and Dyer, 2017), but also generational cohorts and how the value of such resource heterogeneity can be enhanced through both intra- and intergenerational interaction. We used the 'generation' as our unit of analysis in order to disentangle generational heterogeneity over and above that based on family ('transgenerational entrepreneurship view) and business (resource-based view) processes to advance family business research. We therefore contribute a better understanding of 'generation' as a source of heterogeneity in family firms. Our multi-layered model of socialization allows to gain a historical perspective on transferring entrepreneurial orientation concepts and skills to family business successors (Sharma, 2004; Cater et al., 2016), thus integrating the micro (individual), meso (relational) with the macro (context) level of analysis (Jaskiewicz and Dyer, 2017). We have argued that in long-lived family firms there are three forms of socialization, which are better conceived as concentric layers. Which layer becomes 
dominant is highly dependent on the nature of the wider external environment and culture, and the pace of change.

\section{Implications for practice}

The practical implications of our theoretical model's potential in bridging the gaps on socialization in family firms is that it shows there is a need for a more integrated successor development approach where paradox is seen as a vital and necessary element of day-to-day organizing. Paradox is not comprised of independent and exclusive opposites, but it consists of interdependent and complementary opposites. Opposite elements are dynamic as they mutually transform into each other in a balancing process. Successors' training should no longer be planned as an internal process revolving around systemic value transmission from the older to the younger generation (Mazzola et al., 2008; Le Bretton-Miller and Miller, 2015), but rather include peers, mentors, minority shareholders, professional advisers and non-family managers who may not be driven by shared objectives or constitute a successor team (Dalpiaz et al., 2014; Cater et al., 2016). Such training should leave ample room for questioning or transforming assumptions, identities, values and scripts within the family business context rather than emphasize the need to learn, internalize and follow existing cultural codes, knowledge, roles and expectations.

Additionally, where change is rapid, socialization is not just a requirement for successors, but also for the older generation, who would benefit from re-socializing. This study provides a rationale for introducing more formal re-socialization training and mentorship for family business leaders. Family businesses should prioritize equipping all their members for the unexpected, the erratic and the external rather than for the pursuit of longevity, value transmission and harmonious internal ties (Gilding et al., 2015; Bika and Kalantaridis, 2017). Most importantly, the family business itself should not be viewed as an entity that needs to be 'protected' from the outside and thus socialization processes are used for the exclusion of 'outsiders'. Instead of departmental boundaries, ground rules and training tools, we suggest that modern family businesses need more open spaces and collaborative events bringing together diverse stakeholders and recognizing a range of personal 
experiences, shifting roles and emergent strategies in a flexible and changing context.

\section{Directions for Future Research}

The main contribution of this paper has been to raise awareness of the potential of interpretivist theories of socialization for understanding the socialization dynamics of longlived family firms. The propositions offered in this paper provide the basis for more specific research agendas, which could lead to more refined theory and the identification of key constructs. Although the single case approach has allowed for a rich overview and exploration of the socialization processes in the McKay and Mills case, its scope for generalization has been limited by this approach. The next step would be to explore the three socialization layers in other cases adopting a multiple case approach. Of interest would be not only to explore in more detail which forms tends to be most predominant in which context, but also to establish how different forms of socialization and re-socialization interact with each other in different contexts. This can be also done through survey work with family business successors in diverse national contexts and across different generational cohorts (thus increasing the sample). This will help validate our research insight that external conditions cause transgenerational entrepreneurship through re-socialization. Alternatively, an experimental research design involving random assignment to manipulated socialization conditions (internal, interactive and experiential) of family business successors (the population of interest) who engage in entrepreneurial tasks or outcomes (e.g. new products, markets, inputs, technologies or ways of organizing) is suggested. The latter may also vary in terms of 'entrepreneurial orientation' dimensions (e.g. more or less innovative/risktaking/proactive tasks).

We additionally call for research on the non-family socialization influences that should be part of an integrated successor development approach such as peers, minority shareholders, professional advisers and non-family managers and find out how these influences can be managed rather than minimized (Bika and Kalantaridis, 2017). We hope that other family business researchers will join in our endeavour to move the analytical focus away from staged knowledge transfer that often becomes obsolete as the context rapidly 
changes to documenting how non-family stakeholders intermittently bring in the business new knowledge and assist successors' entrepreneurial socialization processes. Research comparing successors in family firms with various levels of family involvement would be particularly interesting in deconstructing entrepreneurial socialization processes. There are no major grounded empirical studies to date on socialization processes within family businesses. Cox (1996: 2) states, for example, that "family values and business values flow down the generations as certainly as rain falls from clouds", but the empirical understandings of this view are still to be convincingly demonstrated. We took a first step towards increasing understanding of the messy socialization process, but also producing better concepts and a multi-layered theoretical proposition that can be observed in situ or tested deductively.

\section{REFERENCES}

Abrantes, P. (2013a). Opening the black box of socialization: Emotions, practices and (biographical) identities. International Journal of Sociology \& Anthropology, 5(9), 391-401. Abrantes, P. (2013b). Socialization and inequality: A biographical approach to the working class in Portugal. Current Sociology, 61(7), 984-1002.

Bar-Yosef, R.-W. (1968). Desocialization and re-socialization: The Adjustment Process of Immigrants. International Migration Review, 2(3), 27-45.

Barbera, F., Bernhard, F., Nacht, J., \& McCann, G. (2015). The Relevance of a Whole-Person Learning Approach to Family Business Education: Concepts, Evidence, and Implications. Academy of Management Learning \& Education, 14(3), 322-346.

Barbera, F., Stamm, I., \& DeWitt, R-L. (2018). The development of an entrepreneurial legacy: Exploring the role of anticipated futures in transgenerational entrepreneurship. Family Business Review, 31(3), 352-378.

Basco, R., Calabro, A., \& Campopiano, G. (2018). Transgenerational entrepreneurship around the world: Implications for family business research and practice. Journal of Family Business Strategy. DOI: $10.1016 / \mathrm{j} . j f b s .2018 .03 .004$

Baxter, P. \& Jack, S. (2008). Qualitative Case Study Methodology: Study Design and 
Implementation for Novice Researchers. The Qualitative Report, 13(4), 544-559.

Bika, Z. \& Kalantaridis, C. (2017). Organizational-social-capital, time and international family SMEs: an empirical study from the East of England. European Management Review DOI: $10.1111 / \mathrm{emre} .12160$

Bhatnagar, K. (2015). Re-socialization and anticipatory socialization. IRA International Journal of Education and Multidisciplinary Studies (ISSN 2455-2526), 1(2).

Cabrera-Suárez, K., De Saá-Pérez, P., \& García-Almeida, D. (2001). The succession process from a resource- and knowledge-based view of the family firm. Family Business Review, 14(1), 37-46.

Cater, J.J. \& Justis, R.T. (2009). The development of successors from followers to leaders in small family firms: An exploratory study. Family Business Review, 22(2), 109-124.

Cater, J.J., Kidwell, R.E., \& Camp, K.M. (2016). Successor team dynamics in family firms. Family Business Review, 29(3), 301-326.

Cope, J. (2005). Toward a dynamic learning perspective of entrepreneurship. Entrepreneurship Theory and Practice, 29(4), 373-397.

Cox, E.S. (1996) The family firm as a foundation of our free society: Strengths and opportunities. Cornell University: Brofenbrenner Life-course Center.

Dalpiaz, E., Tracey, P. \& Phillips, N. (2014). Succession Narratives in Family Business: The Case of Alessi. Entrepreneurship Theory and Practice, 38(6), 1375-1394.

Daspit, J.J., Holt, D.T., Chrisman, J.J. \& Long, R.G. (2016). Examining Family Firm Succession from a Social Exchange Perspective A Multiphase, Multistakeholder Review. Family Business Review, 29(1), 44-64.

Dyck, B., Mauws, M., Starke, F.A., \& Mischke, G.A. (2002). Passing the baton: The importance of sequence, timing, technique and communication in executive succession. Journal of Business Venturing, 17(2), 143-162.

Dyer, W.B. \& Wilkins, A. (1991). Better stories, not better constructs, to generate better theory: A rejoinder to Eisenhardt. Academy of Management Review, 16(3), 613-619.

Eisenhardt, K.M. (1989). Building Theories from Case Study Research. Academy of Management Review, 14(4), 532-550. 
Eisenhardt, K.M. (1991). Better stories and better constructs: The case for rigor and comparative logic. Academy of Management Review, 16(3), 620-627.

Eisenhardt, K.M. \& Graebner, M.E. (2007). Theory Building from Cases: Opportunities and Challenges. Academy of Management Journal, 50(1), 25-32.

Foster, A. (1995). Developing leadership in the successor generation. Family Business Review, 8(4), 201-209.

García-Álvarez, E., López-Sintas, J., \& Gonzalvo, P.S. (2002). Socialization patterns of successors in first- to second-generation family businesses. Family Business Review, 15(3), 189-203.

Gerring, J. (2004). What is a case study and what is it good for? American Political Science Review, 98(2), 341-354.

Gersick, K., Davis, J., McCollom Hampton, M. \& Lansberg, I. (1997). Generation to generation: Life Cycles in Family Business. Boston: Harvard University Press.

Gilding, M. (2010). Reflexivity over and above convention: the new orthodoxy in the sociology of personal life, formerly sociology of the family. British Journal of Sociology, 61(4), 757-777.

Gilding, M., Gregory, S., \& Cosson, B. (2015). Motives and outcomes in family business succession planning. Entrepreneurship Theory and Practice, 39(2), 299-312.

Grbich, C. (1990). Socialization and social change: a critique of three positions. British Journal of Sociology, 41(4), 517-530.

Griffeth, R.W., Allen, D.G., \& Barrett, R. (2006). Integration of family-owned business succession with turnover and life cycle models: development of a successor retention process model. Human Resource Management, 1694, 490-507.

Grusec, J.E. (2011). Socialization Processes in the Family: Social and Emotional Development. Annual Review of Psychology, 62, 243-269.

Haag, K. (2012). Rethinking family business succession. JIBS Dissertation Series. Jönköping: Jönköping International Business School.

Habbershon, T.G., \& Williams, M. (1999). A Resource-Based framework for assessing the strategic advantages of family firms. Family Business Review, 12(1), 1-25. 
Habbershon, T.G., Williams, M.L., \& MacMillan, I.C. (2003). A resource-based framework for assessing the strategic advantages of family firms. Journal of Business Venturing, 18(4), 451-465.

Hamilton, E. (2006). Who's story is it anyway? Narrative accounts of the role of women in founding and establishing family businesses. International Small Business Journal, 24(3), 253-271.

Handler, W.C. (1990). Succession in family firms: a mutual role adjustment between entrepreneur and next-generation family members. Entrepreneurship Theory and Practice $15(1), 37-51$.

Handler, W.C. (1994). Succession in family business: A review of the research. Family Business Review 7(2), 133-157.

Hart, A.P., Miller, V.D., \& Johnson, J.R. (2003). Socialization, re-socialization and communication relationships in the context of an organizational change. Communication Studies, 54(4), 483-495.

Hoy, F. \& Sharma, P. (2010). Entrepreneurial Family Firms. Upper Saddle River: Pearson. James, A.E, Jennings, J.E. \& Breitkruz, R. (2012). World's apart? Re-bridging the distance between family science and family business research. Family Business Review, 25(1), 87-108. Jaskiewicz, P., Combs, J.G., \& Rau, S.B. (2015). Entrepreneurial legacy: Toward a theory of how some family firms nurture transgenerational entrepreneurship. Journal of Business Venturing, 30(1), 29-49.

Jaskiewicz, P. \& Dyer, W.B. (2017). Addressing the elephant in the room: disentangling family heterogeneity to advance family business research. Family Business Review 30(2): $111-118$.

Jennings, J.E., Breitkreuz, R.S. \& James, A.E. (2014). Theories from Family Science: A Review and Roadmap for Family Business Research. In L. Melin, M. Nordqvist \& P. Sharma (Eds.). The Sage Handbook of Family Business. Pp. 25-46. London: Sage.

Jones, G.R. (1983). Psychological orientation and the process of organizational socialization: an interactionist perspective. Academy of Management Review 8(3), 464-474.

Konopaski, M., Jack, S. \& Hamilton, E. (2015) How family business members learn about 
continuity. Academy of Management Learning \& Education, 14(3), 347-364.

Kotlar, J. \& De Massis, A. (2013) Goal setting in family firms: goal diversity, social interactions, and collective commitment to family-centred goals. Entrepreneurship Theory and Practice, 37(6), 1263-1288.

Ladge, J. \& Greenberg, D.N. (2015). Becoming a working mother: Managing identity and efficacy uncertainties during re-socialization. Human Resource Management 54(6), 977-998. Le Breton-Miller, I., \& Miller, D. (2006). Why Do Some Family Businesses Out-Compete? Governance, Long-Term Orientations, and Sustainable Capability. Entrepreneurship Theory and Practice, 30(6), 731-746.

Le Breton-Miller, I., \& Miller, D. (2015). Learning stewardship in family firms: for family, by family, across the lifecycle. Academy of Management Learning \& Education, 14(3), 386399.

Lumpkin, G.T., Brigham, K.H., \& Moss, T.W. (2010). Long-term orientation: Implications for the entrepreneurial orientation and performance of family businesses, Entrepreneurship and Regional Development, 22(3-4), 241-264.

Lumpkin, G.T., \& Brigham, K.H. (2011). Long-Term Orientation and Intertemporal Choice in Family Firms. Entrepreneurship Theory and Practice, 35(6), 1149-1169.

McCorkle, L. \& Korn, R. (1954). Re-socialization within walls. The Annals, 293, 88-98.

Mazzola, P., Marchisio, G., \& Astrachan, J. (2008) Strategic planning in family business: a powerful developmental tool for the next generation. Family Business Review, 21, 239-258.

Merton, R.K. (1957). Social Theory and Social Structure. Glencoe, IL: Free Press.

Miller, D., Steier, L., \& Le Breton-Miller, I. (2003) Lost in time: intergenerational succession, change and failure in family business. Journal of Business Venturing, 18, 513-531.

Milton, L.P. (2008). Unleasing the relationship power of family firms: Identity confirmation as a catalyst for performance. Entrepreneurship Theory and Practice, 32(6), 1063-1081.

Morris, M., Kuratko, D.F., Schindehutte, M. \& Spivack, A.J. (2012). Framing the entrepreneurial experience. Entrepreneurship Theory and Practice, 36(1), 11-40.

Mulholland, K. (1996) 'Gender and Property Relations within Entrepreneurial Wealthy Families', Gender, Work and Organization, 3(2), 78-102. 
Nordqvist, M., Wennberg, K., \& Hellerstedt, K. (2013). An entrepreneurial process perspective on succession in family firms. Small Business Economics, 40, 1087-1122.

Nordqvist, M., \& Zellweger, T. (Eds.) (2010). Transgenerational entrepreneurship: Exploring growth and performance in family firms across generations. Cheltenham: Edward Elgar.

Parsons, T. (1951) The Social System. New York: Free Press.

Perricone, P., Earle, J., \& Taplin, I. (2001). Patterns of succession and continuity in family owned businesses: Study of an ethnic community. Family Business Review, 14(2), 105- 121.

Pilcher, J. (1994). Mannheim's sociology of generations: An undervalued legacy. British Journal of Sociology, 45(3): 481-495.

Rau, S.B. (2014). Resource-based view of family firms. In L. Melin, M. Nordqvist \& P. Sharma (Eds.), The Sage Handbook of Family Business. Pp. 321-340. London: Sage.

Rosa, P., Howorth, C., \& Discua Cruz, A. (2014). Habitual and portfolio entrepreneurship and the family in business". In L. Melin, M. Nordqvist \& P. Sharma (Eds.), The Sage Handbook of Family Business. Pp. 364-382. London: Sage.

Ryan, G.W. \& Bernard, H.R. (2003).Techniques to identify themes. Field Methods, 15(1), 85109.

Salvato, C., Chirico, F., \& Sharma, P. (2010). A farewell to the business: Championing exit and continuity in entrepreneurial family firms. Entrepreneurship and Regional Development, 22(3-4), 321-348.

Sharma, P. (2004). An overview of the field of family business studies: Current status and directions for the future. Family Business Review, 17(1), 1-36.

Sharma, P., Melin, P., \& Nordqvist, M. (2014). Introduction: Scope, evolution, and future of family business studies. In L. Melin, M. Nordqvist \& P. Sharma (Eds.), The Sage Handbook of Family Business. Pp. 1-22. London: Sage.

Siggelkow, N. (2007) Persuasion with Case Studies. Academy of Management Journal, 50(1), $20-24$.

Stake, R.E. (1994). Case Studies In: Denzin, N.K. and Lincoln, Y.S. (Eds.) Handbook of Qualitative Research. Pp. 236-247. London: Sage.

Sutton, R. \& Callahan, A. (1987). The stigma of bankruptcy: Spoiled organizational image 
and its management. Academy of Management Journal, 30, 405-436.

Swann Jr., W.B., Johnson, R.E., \& Bosson, J.K. (2009). Identity negotiation at work. Research in Organizational Behaviour, 29, 81-109.

Walsh, I.J. \& Bartunek, J.M. (2011) Cheating the fates: Organizational foundings in the wake of demise. Academy of Management Journal, 54(5), 1017-1044.

Welch, C., Piekkari, R., Plakoyiannaki, E., \& Paavilainen-Mäntymäki, E. (2011). Theorising from case studies: Towards a pluralist future for international business research. Journal of International Business Studies. 42(6), 740-762.

White, S., Nevitte, N., Blais, A., Gidengil, E. \& Fournier, P. (2008) The Political resocialization of Immigrants: Resistance or Lifelong Learning? Political Research Quarterly, 61(2), 268-281.

Wrong, D.H. (1961). The over-socialized conception of man in modern sociology. American Sociological Review, 26, 183-193.

Yin, R.K. (2009). Case Study Research: Design and Methods. $4^{\text {th }}$ Edition. London: Sage.

Zellweger, T.M., Eddleston, K.A., \& Kellermanns, F.W. (2010). Exploring the concept of familiness: Introducing family firm identity. Journal of Family Business Strategy, 1, 54-63.

Zellweger, T.M., Nason, R.S., \& Nordqvist, M. (2012). From longevity of firms to transgenerational entrepreneurship of families: Introducing family entrepreneurial orientation. Family Business Review, 25(2), 136-155.

Zellweger, T.M. \& Sieger, P. (2012). Entrepreneurial orientation in long-lived family firms. Small Business Economics, 38, 67-84.

Zozimo, R., Jack, S. \& Hamilton, E. (2017). Entrepreneurial learning from observing role models. Entrepreneurship and Regional Development, 29(9-10), 889-911. 
Figure 1: The McKay Family Tree

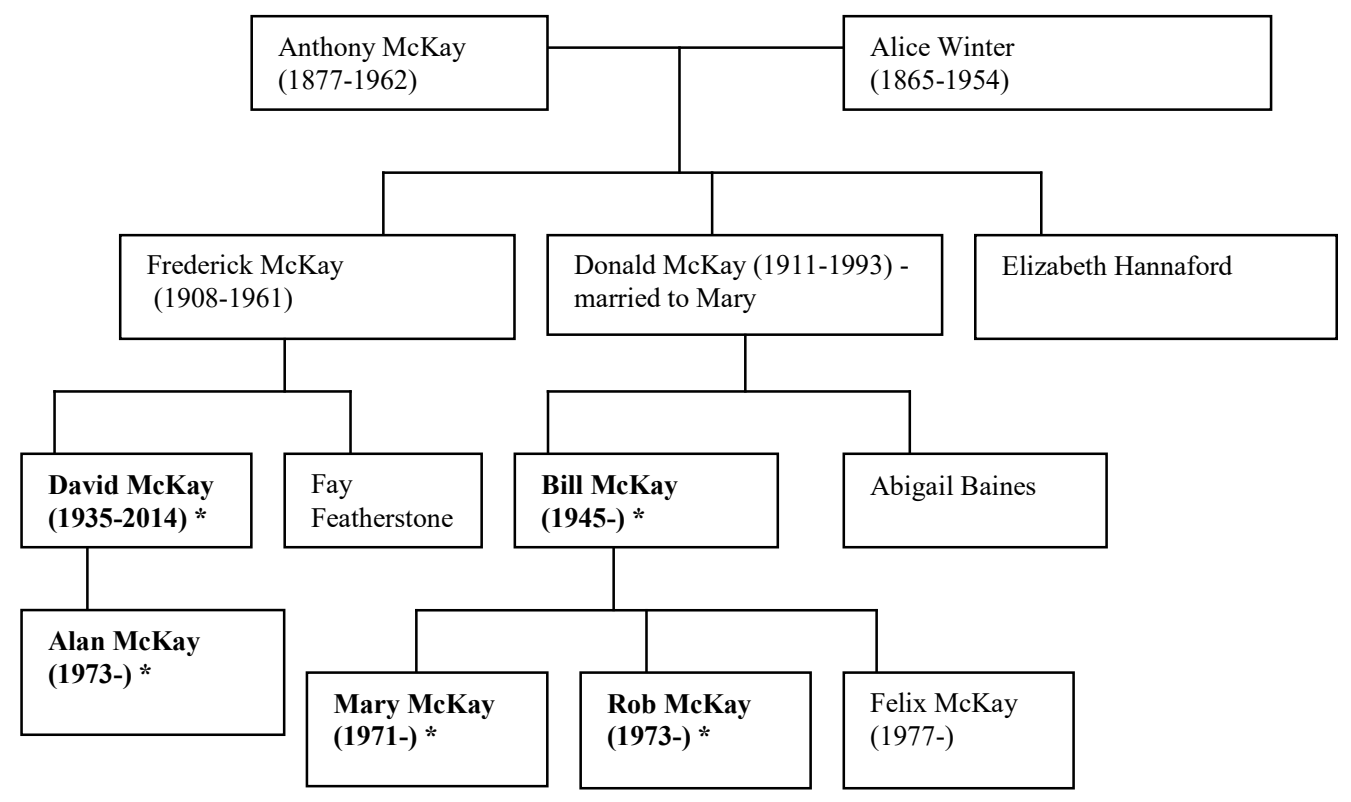




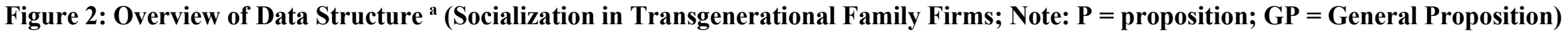

First-Order Codes

(Categories from the Case)
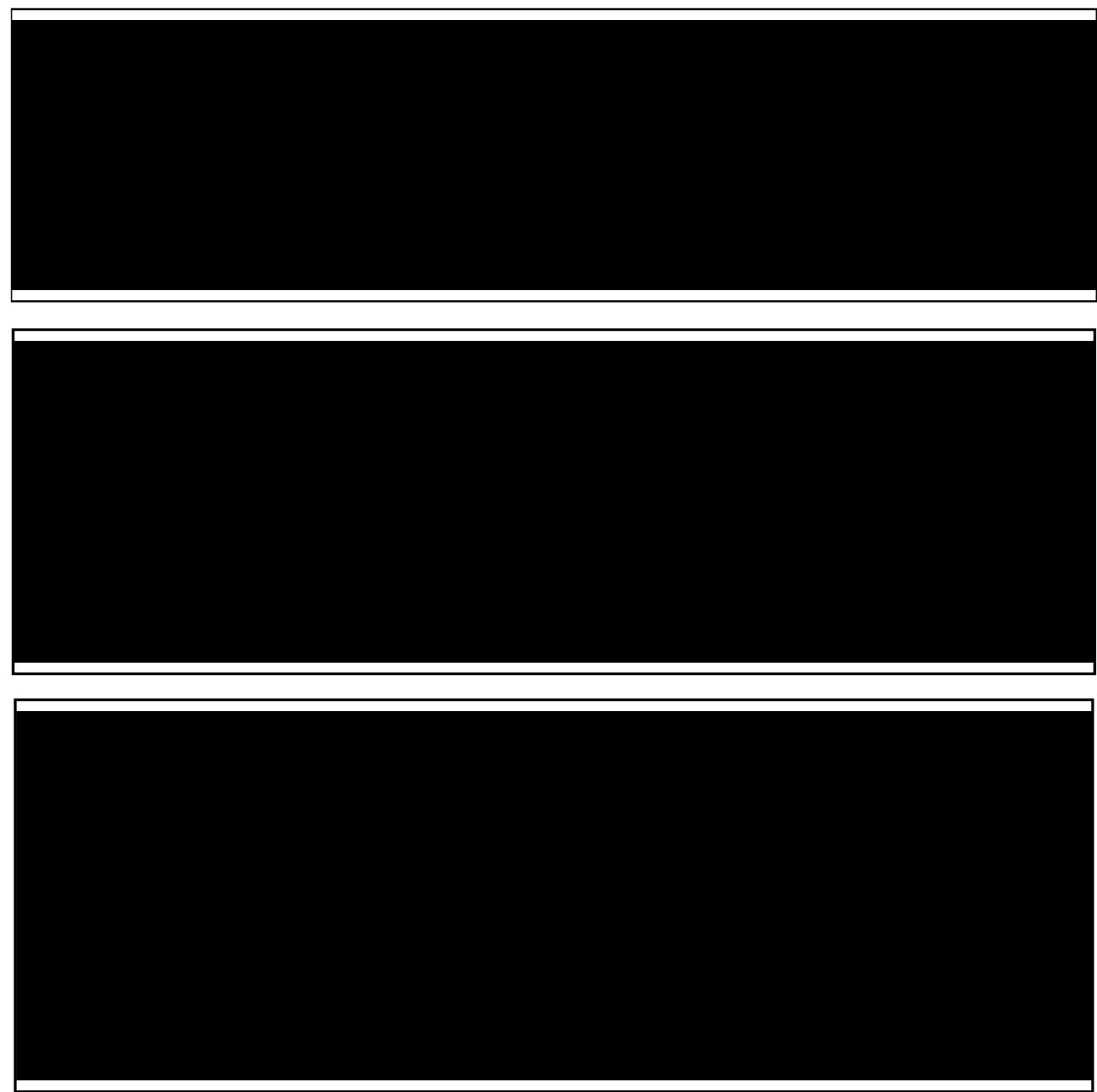

${ }^{a}$ All evidence was derived from face-to-face interviews and secondary data sources.
Second-order Codes

(Theoretical Categories)

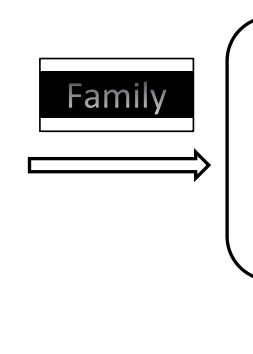

R

\begin{tabular}{|l}
$\mathbf{R}$ \\
$\mathbf{e}$ \\
$\mathbf{s}$ \\
$\mathbf{o}$ \\
$\mathbf{c}$ \\
$\mathbf{i}$ \\
$\mathbf{a}$ \\
$\mathbf{l}$
\end{tabular}

$\mathbf{I}$
$\mathbf{Z}$



$\Longrightarrow$

Experiential

Socialization

ternal

Socialization

(P1)

(P3)

Overarching Theory

(Narrative Strategy) 


\section{Figure 3: Internal, Interactive and Experiential Socialization in transgenerational family firms}

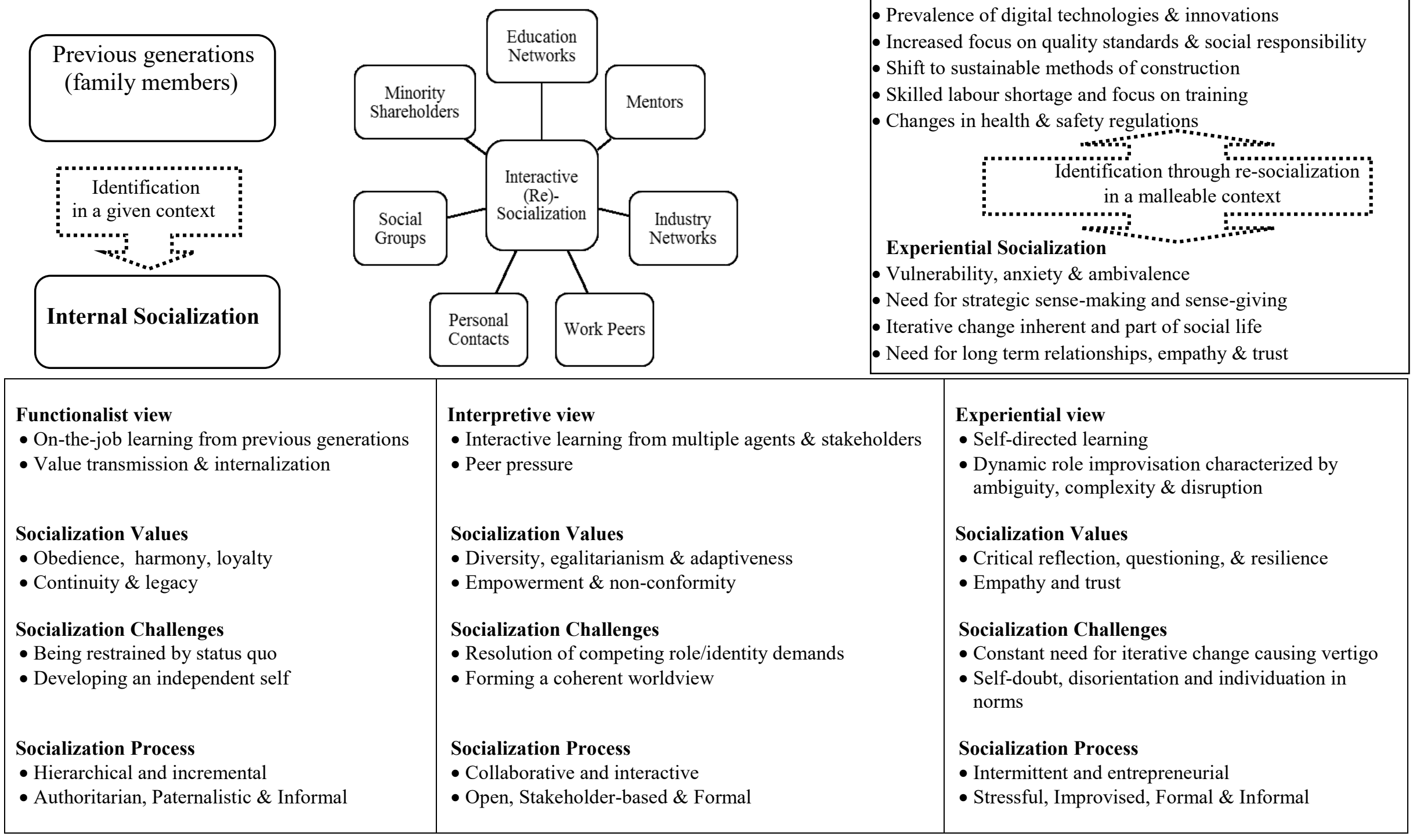


Table 1: Shortened Interview Guide for the STEP Research Project

\begin{tabular}{l} 
Sections \\
\hline Background information \\
on the family and business
\end{tabular}

History and Externalities

\section{Entrepreneurial}

Orientation (autonomy, competitive aggressiveness, innovativeness, proactiveness and risk-taking)

Familiness Resource Pools (leadership, networks, financial capital, decisionmaking, culture, relationships, governance, and knowledge)

\section{Interview Question}

Name of the member, age, and positions covered in the company; position in the family; Other key actors in business and family (family members, non-family managers, advisors)

Describe the historical development of your business or business group with a focus on the family members' role and involvement, the industry in terms of competition, the key environmental forces and the renewal activities that have made a difference in what you are today?

Would you describe the owner-family and business unit as entrepreneurial? Why or why not? How has it changed over time? Describe your family business or group's capabilities to take new actions/initiatives (i.e. to introduce new products, services, processes and ventures). How is it possible to maintain an entrepreneurial spirit as the business passes through generations within the owner-family? Biggest threats to keep the entrepreneurial spirit across generations?

Describe how your family leadership (ownership and management) plays a role in creating an advantage or constraint for your family business or group. Describe how external networks and personal connections play a role in the historical development of your business and/or for generating entrepreneurial opportunities. Describe how your family ownership/control enhances or constrains the allocation of financial capital as it relates to growth and entrepreneurial opportunities. How would you describe the decision-making processes in your businesses or business group? Describe how you believe the culture of the family business or group supports or constrains an entrepreneurial mindset and action over time. The effectiveness of the relationships between family members and the impact on the historical development of your business or business group? Describe the governance of the business or business group - how you have organized the family's ownership in relation to management and entrepreneurship. The extent to which knowledge and competencies have been formed/transferred across generations?

How does the family define and measure success (in monetary and/or non-monetary terms)? How does the family understand/prioritize their performance measures? What are the most important entrepreneurial outcomes to the ownership and management of the business or group (i.e. new products, businesses, innovations, business models, change activities)? If the firm was sold, how would it feel to lose family leadership?

\section{Entrepreneurial} Performance

Table 2: Profile of the Interviewees

\begin{tabular}{|c|c|c|c|c|c|c|c|}
\hline & Company & Alan & Alfred & Bill & Mary & David & Ethan \\
\hline Management Team & 6 & $\mathrm{X}$ & $\mathrm{X}$ & $\mathrm{X}$ & & $\mathrm{X}$ & $\mathrm{X}$ \\
\hline Family Member & 4 & $\mathrm{X}$ & & $\mathrm{X}$ & $\mathrm{X}$ & $\mathrm{X}$ & \\
\hline Lone Founder & 0 & & & & & & \\
\hline Supervisory Board & 3 & $\mathrm{X}$ & & & $\mathrm{X}$ & $\mathrm{X}$ & \\
\hline CEO & 1 & & & & & & $\mathrm{X}$ \\
\hline Employee & 285 & & & & $\mathrm{X}$ & & $\mathrm{X}$ \\
\hline Shareholder & 15 & $\mathrm{X}$ & & $\mathrm{X}$ & $\mathrm{X}$ & $\mathrm{X}$ & \\
\hline Generation & 4 & 4 & $\mathrm{~N} / \mathrm{A}$ & 3 & 4 & 3 & $\mathrm{~N} / \mathrm{A}$ \\
\hline Interview Duration & $408 \mathrm{~min}$ & $67 \mathrm{~min}$ & $58 \mathrm{~min}$ & $102 \min$ & $58 \mathrm{~min}$ & $51 \mathrm{~min}$ & $72 \mathrm{~min}$ \\
\hline Date of Birth & 1925 & 1973 & 1947 & 1945 & 1971 & 1935 & 1964 \\
\hline Nationality & British & $\begin{array}{c}\text { British } \\
\text { Town }\end{array}$ & $\begin{array}{c}\text { British } \\
\text { Chartered }\end{array}$ & British & $\begin{array}{c}\text { British } \\
\text { Marketing }\end{array}$ & British & $\begin{array}{l}\text { British } \\
\text { Company }\end{array}$ \\
\hline Occupation & $\mathrm{N} / \mathrm{A}$ & Planner & Accountant & Architect & Manager & Architect & Director \\
\hline Directorship & 5 & Yes & Yes & Yes & No & Yes & Yes \\
\hline
\end{tabular}

Table 3: Secondary Data Sources

\begin{tabular}{rlc}
\hline \multicolumn{1}{r|}{ Items } & & Number of Items \\
\hline 1. & Annual Reports (2007-2017) & 10 \\
2. & Interview Transcripts of deceased generations' members (1880-1999) & 3 \\
3. & Company Website & 1 \\
4. & Other online newspaper material, press releases (2007-2017) & 12 \\
5. & Published books on the history of the Scottish house building (1880- & 1 \\
& 1999) & 1 \\
6. & STEP case study protocol (2008) & 1 \\
\hline
\end{tabular}




\section{Table 4: How a wide variety of external agents influence interactive re-socialization}

\begin{tabular}{|c|c|}
\hline Items & Illustrative Data Excerpts \\
\hline Education & $\begin{array}{l}\text { "My second degree in Sydney Australia (for two years) ... seven years of experience of working in advertising } \\
\text { and working on the client side doing marketing for companies, and it came to me slowly, there is another brand } \\
\text { that I know so well ... why am I wasting my time really working for other people" (Mary McKay) }\end{array}$ \\
\hline Mentors & $\begin{array}{l}\text { "My ethos is not to be the person that makes all of the decisions all the time. I simply want to steer other people } \\
\text { through the various issues that we have to come out with the best outcome for the company ... when you work in } \\
\text { a family business they find it difficult to say thank you because they have that, you know, not quite sure who } \\
\text { should be thanking who sort of approach" (Ethan, CEO) }\end{array}$ \\
\hline Industry & $\begin{array}{l}\text { "(Building) very fast, huge numbers of men, very tightly controlled by the company and not so tightly controlled } \\
\text { by the authorities. To make it happen successfully somebody had to really be on top of it but in today's climate } \\
\text { that's much harder because you've all the outside official bodies looking in which they didn't have" (Bill McKay) }\end{array}$ \\
\hline $\begin{array}{l}\text { Personal } \\
\text { Contacts }\end{array}$ & $\begin{array}{l}\text { "We were always very known, if our company had a project on that was controversial locally (e.g. if you are } \\
\text { developing on a school playing field), you would always get the feeling that we would move to the other side of } \\
\text { the street or have something to say about it" (Alan McKay) }\end{array}$ \\
\hline $\begin{array}{l}\text { Minority } \\
\text { Share- } \\
\text { holders }\end{array}$ & $\begin{array}{l}\text { "We were able to say to shareholders you'll do exactly what we tell you and that's an end of it ... (Now) I'm just } \\
\text { nervous, not nervous for us but rather that the shareholders can rock a private company because you need } \\
\text { confidence. If your customers think there's something funny here. We're as susceptible to that as a PLC is and } \\
\text { maybe we (like) to think we're not, we are it's just the forces come in a different way" (Bill McKay) }\end{array}$ \\
\hline \multirow[t]{2}{*}{$\begin{array}{l}\text { Work } \\
\text { Peers }\end{array}$} & $\begin{array}{l}\text { "I think what's changed certainly in the last } 5 \text { to } 6 \text { years in construction sector is pretty much full employment, in } \\
\text { fact shortages of labour/skilled managers, so when that changes then that type of (authoritarian and very } \\
\text { committed) leadership can be seen as being a bit abrasive and will say well you know why do I put up with this } \\
\text { here if I can go somewhere else" (Ethan, CEO) }\end{array}$ \\
\hline & $\begin{array}{l}\text { "(Alan McKay) is passionate about the business, will listen to what others have to say and make a reasoned } \\
\text { decision" (Alfred, Finance Director) }\end{array}$ \\
\hline
\end{tabular}


Table 5: Mapping Environmental Changes and Experiential Socialization

\begin{tabular}{|c|c|c|}
\hline $\begin{array}{c}\text { Paradigm } \\
\text { Shifts \& } \\
\text { Environment } \\
\text { al Changes }\end{array}$ & $\begin{array}{c}\text { Indicators of } \\
\text { influence and } \\
\text { personal } \\
\text { change }\end{array}$ & $\begin{array}{l}\text { Evidence of experiential socialization and its manifestations (Quotes illustrating } \\
\text { consequences of changes, changes in behaviours or feelings, and resulting patterns of } \\
\text { socialization) }\end{array}$ \\
\hline \multirow{6}{*}{$\begin{array}{c}\text { Prevalence of } \\
\text { digital } \\
\text { technologies } \\
\& \\
\text { innovations }\end{array}$} & $\begin{array}{c}\text { Challenges to } \\
\text { traditional } \\
\text { ways of doing } \\
\text { business }\end{array}$ & $\begin{array}{l}\text { "The company has changed beyond recognition during the course of Bill's career, from a } \\
\text { pyramid structure with the directors at the top, fewer drawings and regulations and a lot of } \\
\text { decisions made on site, to a modern company of specialised departments, external agents, } \\
\text { engineers and subcontractors, with BIM software and site and project teams in constant } \\
\text { interaction ... changed our structure from a traditional department-led approach to creating } \\
\text { multi-disciplined teams; this re-engineering was completed this year" (Annual Report, 2017) }\end{array}$ \\
\hline & $\begin{array}{l}\text { Vulnerability, } \\
\text { anxiety and } \\
\text { ambivalence }\end{array}$ & $\begin{array}{l}\text { "Each generation views life differently, they learn from us and we learn from them" (Bill } \\
\text { McKay) } \\
\text { "From the newest apprentice on our building sites to the oldest of hands, from the youngest } \\
\text { office worker to the longest-serving board member, we put significant time and energy in } \\
\text { their development. In uncertain economic times, loyalty is a two-way process that benefits us } \\
\text { all ... our roots might be old but we are forever young in our thinking ... you are only ever } \\
\text { as good as the customer says you are" (Annual Report, 2011) }\end{array}$ \\
\hline & $\begin{array}{l}\text { Creative use } \\
\text { of digital } \\
\text { design tools } \\
\text { and } \\
\text { technological } \\
\text { resources }\end{array}$ & $\begin{array}{l}\text { "While many believe automation can lead to a reduced workforce, we have actually invested } \\
\text { further in staff training and upskilling employees in the use of the new machinery" (Annual } \\
\text { Report, 2016); or "we utilize social media to excite target audiences" (Annual Report, 2017) } \\
\text { "I opened the first PC in 1991, took it out and put it on the desk, people gathered round it ... } \\
\text { what capability it gave me as a young buyer was absolutely tremendous, because I could do } \\
\text { things which my predecessors could only dream about doing in terms of creating take offs } \\
\text { and schedules and standard formats for taking the materials from a house, and developing a } \\
\text { whole range of standard houses" (Ethan, CEO)" }\end{array}$ \\
\hline & $\begin{array}{l}\text { Continuous } \\
\text { learning for } \\
\text { innovation }\end{array}$ & $\begin{array}{l}\text { "Manufacturing offsite (timber kits), we not only realise substantial time savings over } \\
\text { traditional methods, we are able to guarantee supply" (Annual Report, 2010) } \\
\text { "In my father's day anybody who did anything on our site was paid by us. So, we used to dig } \\
\text { all our own trenches, fit in our own sewers, put in our own roads all of that, we don't do that } \\
\text { now, we used to. So, we've taken out some of the trades that we did" (Bill McKay). }\end{array}$ \\
\hline & $\begin{array}{l}\text { Willingness to } \\
\text { break } \\
\text { established } \\
\text { habits and } \\
\text { transcend } \\
\text { existing } \\
\text { organisational } \\
\text { structures and } \\
\text { rules }\end{array}$ & $\begin{array}{l}\text { "The new group structure will allow us to grow and diversify into other areas such as } \\
\text { commercial development and gives us the option if we ever want to create a standalone land } \\
\text { trading company or commercial property business. Any new companies which are formed } \\
\text { will sit below the McKay Group" (Company Newsletter, 2008). } \\
\text { "The directors have got cellular offices but everything else is open plan ... moving offices } \\
\text { was an opportunity to change the culture a little bit as well, because I would like to think that } \\
\text { probably in the old office it was a little bit more dictatorial and here we have more, there are } \\
\text { management meetings more and every department is encouraged to come up with new ideas, } \\
\text { and we can see each other much more as well ... now there is a more collegiate approach } \\
\text { because the directors all do speak to each other" (Alan McKay) }\end{array}$ \\
\hline & $\begin{array}{l}\text { Embracing } \\
\text { uncertainty } \\
\text { and } \\
\text { discontinuity }\end{array}$ & $\begin{array}{l}\text { "This is happening in tougher times - rising costs, market consolidation, new entrants to the } \\
\text { market. We will be spending the summer meeting Government Ministers and the banking } \\
\text { industry to find solutions to turnaround the trend of few mortgage products" (Newsletter, } \\
\text { 2008) } \\
\text { "The older generation has the confidence in Ethan, Alan and myself not to say oh god this is } \\
\text { too scary, we don't want to go there. They've listened to our arguments, and said yes let's go } \\
\text { for it e.g. employee share options" (Alfred) }\end{array}$ \\
\hline
\end{tabular}




\begin{tabular}{|c|c|c|}
\hline $\begin{array}{c}\text { Shift to } \\
\text { sustainable } \\
\text { methods of } \\
\text { construction }\end{array}$ & $\begin{array}{c}\text { Increased } \\
\text { commitment } \\
\text { to minimising } \\
\text { waste }\end{array}$ & $\begin{array}{l}\text { "On an environmental level, we are celebrating the recent achievement of our Code } 4 \\
\text { Ecohome, delivered through the efforts of our Sustainable Working Party. We are committed } \\
\text { to going beyond regulations in Waste Management, Energy Efficiency and new methods of } \\
\text { heat generation (Annual Report, 2009) } \\
\text { "One of the things that's been raised in the shareholder liaison group which is tremendously } \\
\text { commendable is one of the members who does not work for the company is very keen on } \\
\text { green issues and really stands up at the meetings and say I want to know what you're doing, } \\
\text { I'm a shareholder and I have a right to know how you minimise carbon foot printing" (Bill) }\end{array}$ \\
\hline $\begin{array}{l}\text { Increased } \\
\text { sense of } \\
\text { responsibility } \\
\text { to develop } \\
\text { sustainable } \\
\text { houses and } \\
\text { solutions }\end{array}$ & $\begin{array}{l}\text { Developing an } \\
\text { environmental } \\
\text { view and } \\
\text { collaborative } \\
\text { relationships } \\
\text { with } \\
\text { stakeholders }\end{array}$ & $\begin{array}{l}\text { "We are responsible, we don't build a development, create a community and then run away } \\
\text { you know, we like to enjoy what we are doing and think that in 10-15 years on people are } \\
\text { still having a good experience" (Alan McKay)" } \\
\text { "We take our commitment to the families and communities in which we build very seriously, } \\
\text { investing substantial amounts every year in sports pitches, community halls, play parks, and } \\
\text { other facilities to improve the environment of our developments ... It is important that our } \\
\text { developments sit in harmony with the local landscape ... We frequently commission } \\
\text { environmental impact studies ... we are particularly committed to striving for zero } \\
\text { maintenance in our homes, which, above all, are built to last" (Annual Report, 2007). }\end{array}$ \\
\hline \multirow{2}{*}{$\begin{array}{l}\text { Bridging the } \\
\text { skills gap } \\
\text { Investment in } \\
\text { employees and } \\
\text { their training }\end{array}$} & $\begin{array}{l}\text { Increased } \\
\text { managerial } \\
\text { capacity for } \\
\text { strategic } \\
\text { sense-making } \\
\text { and sense- } \\
\text { giving }\end{array}$ & $\begin{array}{l}\text { "The construction industry is possibly more prone than others to a skills gap. We work hard } \\
\text { to train and retain our talented employees and recognize that the Investors in People standard } \\
\text { assists us in that process" (Newsletter, 2007) } \\
\text { "You have got to be able to attract new talented people to the business in the future ... We } \\
\text { just needed more proactive management, so in the last year we have brought in the } \\
\text { performance review and that is going to create a few changes because we will probably start } \\
\text { losing staff that we don't think are performing as well, and that is a cultural change a little bit } \\
\text { as well because we haven't had that attitude very much" (Alan McKay) }\end{array}$ \\
\hline & $\begin{array}{l}\text { Increased } \\
\text { ability to } \\
\text { inspire \& } \\
\text { mobilise } \\
\text { people }\end{array}$ & $\begin{array}{l}\text { "To empower our staff to get involved in business improvement and decision making, five } \\
\text { employee-led teams were formed to present action plans to the board. } 66 \text { of the } 77 \text { proposals } \\
\text { presented were approved ... We have held Investors in People accreditation since } 2008 \text { and } \\
\text { were proud to progress to Gold standard in early } 2015 \text { " (Annual Report, 2015) } \\
\text { "This manager on a site was really making a mess in the great scheme of things we probably } \\
\text { should have fired him but we both said, you know, this guy's got some potential we're } \\
\text { failing him, we're not bringing out what he's good at, let's have a go at him. The building } \\
\text { manager and I went } 3 \text { days a week for a couple of months to this site with this guy. If you } \\
\text { develop people's skills, you actually are sending out little hooks all the time. We started } \\
\text { recruiting recently and somebody came up with the idea of why don't we approach people } \\
\text { that have left us; it's almost legitimate headhunting" (Bill McKay) }\end{array}$ \\
\hline \multirow[t]{2}{*}{$\begin{array}{l}\text { Changes in } \\
\text { Health and } \\
\text { safety } \\
\text { regulations } \\
\text { Commitment } \\
\text { to developing } \\
\text { a better } \\
\text { working } \\
\text { environment } \\
\text { for all staff } \\
\end{array}$} & $\begin{array}{l}\text { A } \\
\text { commitment } \\
\text { to continuous } \\
\text { investments to } \\
\text { improve } \\
\text { health and } \\
\text { safety } \\
\text { standards in } \\
\text { all sites }\end{array}$ & $\begin{array}{l}\text { "Health and safety continues to be a priority and we proactively promote this through } \\
\text { rigorous training and (prevention) initiatives across all of our outlets. Accident rates are } \\
\text { down and near miss reporting has increased, showing greater awareness among staff of the } \\
\text { need to flag up potential issues" (Annual Report, 2016) } \\
\text { "Handcrafted homes for generations: we like to enjoy what we are doing and think that in } \\
10-15 \text { years people are still having a good experience" (Mary McKay) } \\
\text { "We have still got a really strong pension and a solution for people with a benefits scheme, } \\
\text { we have still got our defined benefits and hardly anyone has that and there is BUPA private } \\
\text { health care that people have as well so if people wanted to move to another job at another } \\
\text { company they might not get all those benefits" (Alan McKay) }\end{array}$ \\
\hline & $\begin{array}{l}\text { Commitment } \\
\text { to achieving } \\
\text { highest quality } \\
\text { standards in } \\
\text { the industry }\end{array}$ & $\begin{array}{l}\text { "Our reputation for quality and exacting standards is regularly recognised through (leading } \\
\text { national and international) awards (for customer service and housing design). When it comes } \\
\text { to raising the bar in terms of craftsmanship, breadth of innovation and attention to detail, } \\
\text { these achievements inform our forward thinking for future projects" (Annual Report 2007) } \\
\text { "This (new 'best building practices') manager would be the one that goes and have meetings } \\
\text { with other builders and say we're not building these exactly the right way" (Bill McKay) }\end{array}$ \\
\hline
\end{tabular}


